\title{
High Temperature Effect on Multicrystalline Photovoltaic Module in Western Rajasthan, India
}

\author{
Shalini Garg \\ Government Polytechnic College, \\ Jodhpur, India
}

\author{
Arun J.B. \\ Directorate of Technical Education, \\ Jodhpur, India
}

\begin{abstract}
The literature and research papers all show that PV (Photovoltaic) module have maximum efficiency at $25^{\circ} \mathrm{C}$. However on analysing the real time data of a $5 \mathrm{MW}$ (Mega Watt) PV (Photovoltaic) power plant located at Ramgarh, district Jaisalmer, India, it was found that the DC output voltage of a multicrystalline module is not maximum at $25^{\circ} \mathrm{C}$, instead much higher DC voltage is obtained at $40^{\circ} \mathrm{C}$ ambient temperature and stable voltage is obtained only if ambient temperature is greater than about $37^{\circ} \mathrm{C}$ and panel temperature is greater than $50^{\circ} \mathrm{C}$. DC output voltage decreases slightly with increase in panel temperature only after panel temperature crosses $52^{\circ} \mathrm{C}$ but the output obtained even at $68^{\circ}$ $\mathrm{C}$ is much higher than that obtained at $30-35^{\circ} \mathrm{C}$ panel temperature roughly corresponding to $25-28^{\circ} \mathrm{C}$ ambient temperature. Since the power output is directly proportional to the voltage, Western Rajasthan has a great potential to become a leader in solar photovoltaic.
\end{abstract}

\section{General Terms}

Multicrystalline Photovoltaic Module, Solar Energy.

\section{Keywords}

Photovoltaic Module, Solar Energy, Multicrystalline, Polycrystalline, Amorphous silicon, PV cell.

\section{INTRODUCTION}

In Western Rajasthan where the pre-monsoon average temperature which extends from April to June varies in the range of minimum of $32^{\circ} \mathrm{C}$ to maximum of $45^{\circ} \mathrm{C}$, with record maximum temperature of $48^{\circ} \mathrm{C}$, it seems as though Western Rajasthan is not suitable for solar photovoltaic [1]. A typical photovoltaic module is built as an array of multiple interconnected photovoltaic cells, which converts solar energy into electric energy [2]. Several kinds of modules are commercially available: crystalline silicon (c-Si), which can be either monocrystalline silicon (mono-Si) or polycrystalline silicon (poly-Si) and amorphous silicon (a-Si). Polycrystalline consists of small crystals, also known as crystallites, giving the material its typical metal flake effect. Although polycrystalline and multicrystalline are often used as synonyms, multicrystalline usually refers to crystals larger than $1 \mathrm{~mm}$ (millimetre) [3]. Other technologies are also available, but their commercial impact is so far limited. Different modules differ in their characteristic and efficiency due to difference in material, structure and packing, responding differently in various environmental conditions like solar irradiation, ambient temperature, cell temperature, wind speed, humidity, air pressure, dust, tilt angle etc.

The photovoltaic (PV) modules are rated in DC watts at STC (Standard Test Conditions). That is cells are tested and rated at irradiance of $1000 \mathrm{~W} / \mathrm{m}^{2}, \mathrm{PV}$ cell temperature $25^{\circ} \mathrm{C}$ and air mass equal to1.5. Any deviation from the standard condition affects the power output of the module. Solar radiation is the main influence on PV module output. Roughly speaking, module output is proportional to the irradiance level [4]. Temperature is the second most important effect. The general rule is the higher the temperature, the lower the PV efficiency [2]. Typically voltage decreases with increasing temperature, and current increases (although slightly), the combined effect being that power decreases [4].

There are two distinct voltage coefficient values, one for $\mathrm{V}_{\text {oc }}$ and one for $\mathrm{V}_{\text {mpp }}$. The coefficient value for $\mathrm{V}_{\text {oc }}$ is always less than the coefficient for $V_{\text {mpp }}$ [5]. The specification sheet generally specify temperature coefficient for $\mathrm{P}_{\max }$ and $\mathrm{V}_{\text {oc }}$. Temperature coefficients for the maximum power are reported as $-0.5 \% /{ }^{\circ} \mathrm{C}$ for poly-Si (Polysilicon or Polycrystalline) and $0.25 \% /{ }^{\circ} \mathrm{C}$ for a-Si (amorphous silicon) [4]. The negative $\mathrm{P}_{\max }$ coefficient show inverse relationship between temperature and dc power. Similarly negative $\mathrm{V}_{\mathrm{oc}}$ temperature coefficient show inverse relationship between temperature and open circuit voltage [5]. A polycrystalline module operating typically at $45^{\circ} \mathrm{C}$ will therefore produce roughly $10 \%$ less power than predicted by its nominal STC rating [4]. The temperature coefficient and other performance parameters of a PV module are specific to the type of module [6]. It also depends upon specific location as environmental conditions vary widely over the world. The impact of high temperature on a multicrystalline PV module in Western Rajasthan where the temperature goes as high as $48^{\circ} \mathrm{C}$ has been analysed. Western Rajasthan is bestowed with perennial and abundant solar radiation, along with large unutilized low cost desert land and scanty rainfall. It has the potential to become the hub for solar power technologies and become the largest provider of solar power at a competitive cost transforming the complete economic scenario. The paper provides important and useful information with respect to extreme climatic conditions of Western Rajasthan.

The characteristic investigations of PV technologies shown in Table 1, illustrate the temperature coefficient for different types of modules for a specific site [7].

Table 1. Characteristic investigation of PV technologies

\begin{tabular}{|l|c|c|c|}
\hline PV technology & $\begin{array}{l}\text { NOCT } \\
\text { in }{ }^{\circ} \mathrm{C}\end{array}$ & $\begin{array}{l}\text { Module } \\
\text { efficiency } \\
\eta_{\mathrm{STC}}(\%)\end{array}$ & $\begin{array}{l}\text { Temperature } \\
\text { coefficient } \\
\text { of maximal } \\
\text { power }\left(\beta_{\mathrm{STC})}\right. \\
\text { in \% }{ }^{\circ} \mathrm{K}\end{array}$ \\
\hline $\begin{array}{l}\text { Monocrystalline } \\
\text { silicon (m-Si) }\end{array}$ & 45 & 18.4 & -0.38 \\
\hline $\begin{array}{l}\text { Polycrystalline } \\
\text { silicon (p-Si) }\end{array}$ & 46 & 14.1 & -0.45 \\
\hline
\end{tabular}




\begin{tabular}{|l|c|c|c|}
\hline $\begin{array}{l}\text { Amorphous silicon } \\
(\mathrm{a}-\mathrm{Si})\end{array}$ & 46 & 6.0 & -0.19 \\
\hline $\begin{array}{l}\text { Microcrystalline } \\
\text { silicon }(\mu \mathrm{c}-\mathrm{Si})\end{array}$ & 44 & 9.5 & -0.24 \\
\hline $\begin{array}{l}\text { Cadmium telluride } \\
(\mathrm{CdTe})\end{array}$ & 45 & 10.7 & -0.25 \\
\hline
\end{tabular}

Depending upon the type of module the $\mathrm{P}_{\max }$ temperature coefficient varies in the range of $-19 \% /{ }^{\circ} \mathrm{K}$ to $-38 \%{ }^{\circ} \mathrm{K}$. This may further vary from site to site.

$$
\begin{aligned}
& \text { As } P_{\max }=V_{m p p}{ }^{*} I_{m p p} \\
& P_{d c}=V_{d c}{ }^{*} I_{d c}
\end{aligned}
$$

It is thus desirable to investigate the influence of high ambient and panel temperature on the dc voltage. The $\mathrm{P}_{\max }$ and $\mathrm{V}_{\mathrm{oc}}$ temperature coefficient values for multicrystalline module that has been analysed are $-0.447 \% /{ }^{\circ} \mathrm{K}$ and $-0.353 \%$ $/{ }^{\circ} \mathrm{K}$ respectively as shown in Table 2 . The study analysis was done by collecting the data from 5MW grid connected solar power plant located in Ramgarh, district Jaisalmer, one of the hottest cities of Western Rajasthan.

\section{METHODOLOGY}

2.1 The data set used in analysis is from one of the $5 \mathrm{MW}, \mathrm{PV}$ power plant located at Ramgarh, in district Jaisalmer, Rajasthan, India.

2.2 The real time data is recorded by weather station and multifunction meter at 15 minutes interval.

2.3 SCADA (Supervisory Control And Data Acquisition) system is used for monitoring and collecting data from remote site and to transfer the data to the computer for storage and report generation.

2.4 All modules are oriented towards south at $30^{\circ}$ tilt angle, in winters the tilt angle is changed to $5^{\circ}$.

2.5 The data and result correspond to multicrystalline module with specifications as shown in Table 2. The characteristic of the PV module are specified at STC condition as shown in Table 3.

2.6 The average DC voltage of five arrays with maximum possible array voltage of $735.6 \mathrm{~V}(24 * 30.64)$ has been analysed with reference to ambient temperature and average panel temperature of five arrays during premonsoon season.

2.7 Among all major environmental parameters, only ambient temperature and panel temperature has been considered for the present study.

2.8 The 24 hours data recorded at 15 minutes interval has been reduced to the data corresponding to peak sun hours. Numbers of peak sun hours describe the number of hours each day that the irradiance value is equal to $1000 \mathrm{~W} / \mathrm{m}^{2}$. However NREL (National Renewable Energy Laboratory) has redefined peak sun hours or insolation as the solar energy received at a site over the course of the day [5]. Recorded data shows approximately daily sun hour average of 5.5 hours for many Southern California locations [8]. The amount of Sun Hours for one particular location differs from day to day. Ramgarh has about 10-12 peak sun hours in the premonsoon season.
2.9 Data and result shown in next section correspond to the typical data among the obtained.

Table 2. MBSL elite PV module characteristic

\begin{tabular}{|c|l|l|}
\hline S.No & $\begin{array}{l}\text { ELECTRICAL } \\
\text { CHARACTERISTICS }\end{array}$ & VALUES \\
\hline 1. & Maximum power $\mathrm{P}_{\text {mpp }} / \mathrm{P}_{\max }$ & $247.39 \mathrm{~W}$ \\
\hline 2. & Voltage at $\mathrm{P}_{\max }, \mathrm{V}_{\mathrm{mpp}}$ & $30.64 \mathrm{~V}$ \\
\hline 3. & Current at $\mathrm{P}_{\max }, \mathrm{I}_{\mathrm{mpp}}$ & $8.07 \mathrm{~A}$ \\
\hline 4. & Open circuit voltage $\mathrm{V}_{\mathrm{oc}}$ & $37.67 \mathrm{~V}$ \\
\hline 5. & Short circuit current $\mathrm{I}_{\mathrm{sc}}$ & $8.26 \mathrm{~A}$ \\
\hline 6. & Temperature coefficient of $\mathrm{P}_{\mathrm{max}}$ & $-0.447 \% /{ }^{\circ} \mathrm{K}$ \\
\hline 7. & Temperature coefficient of $\mathrm{V}_{\mathrm{oc}}$ & $-0.353 \% /{ }^{\circ} \mathrm{K}$ \\
\hline 8. & Temperature coefficient of $\mathrm{I}_{\mathrm{sc}}$ & $0.104 \% /{ }^{\circ} \mathrm{K}$ \\
\hline 9. & Power Tolerance & $-0 /+5 \mathrm{~W}$ \\
\hline 10. & Fuse rating & $15 \mathrm{~A}$ \\
\hline 11. & Maximum System Voltage & $1000 \mathrm{~V}$ \\
\hline 12. & Maximum array voltage & $\begin{array}{l}735.36 \mathrm{~V} \\
(24 * 30.64)\end{array}$ \\
\hline
\end{tabular}

Table 3. STC condition

\begin{tabular}{|c|l|l|}
\hline 3 & Parameters & Value \\
\hline 1 & Irradiance & $1000 \mathrm{~W} / \mathrm{m}^{2}$ \\
\hline 2 & Module Temperature & $25^{\circ} \mathrm{C}$ \\
\hline 3 & Air Mass & 1.5 \\
\hline 4 & $\begin{array}{l}\text { NOCT (Nominal Operating } \\
\text { Cell Temperature) }\end{array}$ & $47^{\circ} \mathrm{C}$ \\
\hline 5 & Operating Temperature & $-40^{\circ} \mathrm{C}$ to $+85^{\circ} \mathrm{C}$ \\
\hline
\end{tabular}

\section{EXPERIMENTAL DATA ANALYSIS}

The effect of ambient temperature and panel temperature on dc output voltage of the array has been analysed for multicrystalline photovoltaic module in Jaisalmer district during summer when Western Rajasthan records highest temperature. Figure 1 and figure 3 show variations for three different days in pre-monsoon season when ambient temperature is in the range of $38-45^{\circ} \mathrm{C}$ for quite long duration (7 to 8 hours). The VDC1, VDC2 and VDC3 in these two figures correspond to the DC voltage for three different days respectively. 


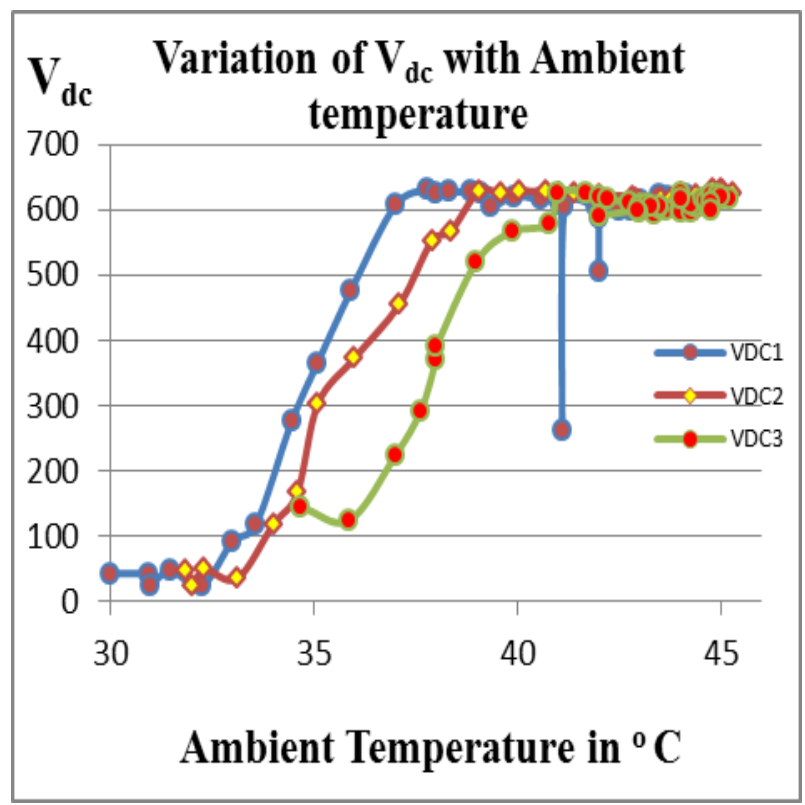

Figure 1: Variation of $V_{d c}$ with ambient temperature

The above figure shows that $\mathrm{V}_{\mathrm{dc}}$ increases with increase in ambient temperature. Nearly stable and high $\mathrm{V}_{\mathrm{dc}}$ is obtained for ambient temperature greater than around $37 / 38^{\circ} \mathrm{C}$.

Figure 2 shows expanded view of variation of $\mathrm{V}_{\mathrm{dc}}$ for one of the day, considering ambient temperature greater than $38^{\circ} \mathrm{C}$. $\mathrm{V}_{\mathrm{dc}}$ decreases slightly with increase in ambient temperature above $40^{\circ} \mathrm{C}$ but again increases around $44 / 45^{\circ} \mathrm{C}$. High $\mathrm{V}_{\mathrm{dc}}$ that is $626 \mathrm{~V}$ at ambient temperature $45.28^{\circ} \mathrm{C}$ and $631.96 \mathrm{~V}$ at $44.80^{\circ} \mathrm{C}$ is observed. $\mathrm{V}_{\mathrm{dc}}$ varies between $628 \mathrm{~V}-631 \mathrm{~V}$ as ambient temperature varies between $38^{\circ} \mathrm{C}$ to $46^{\circ} \mathrm{C}$.

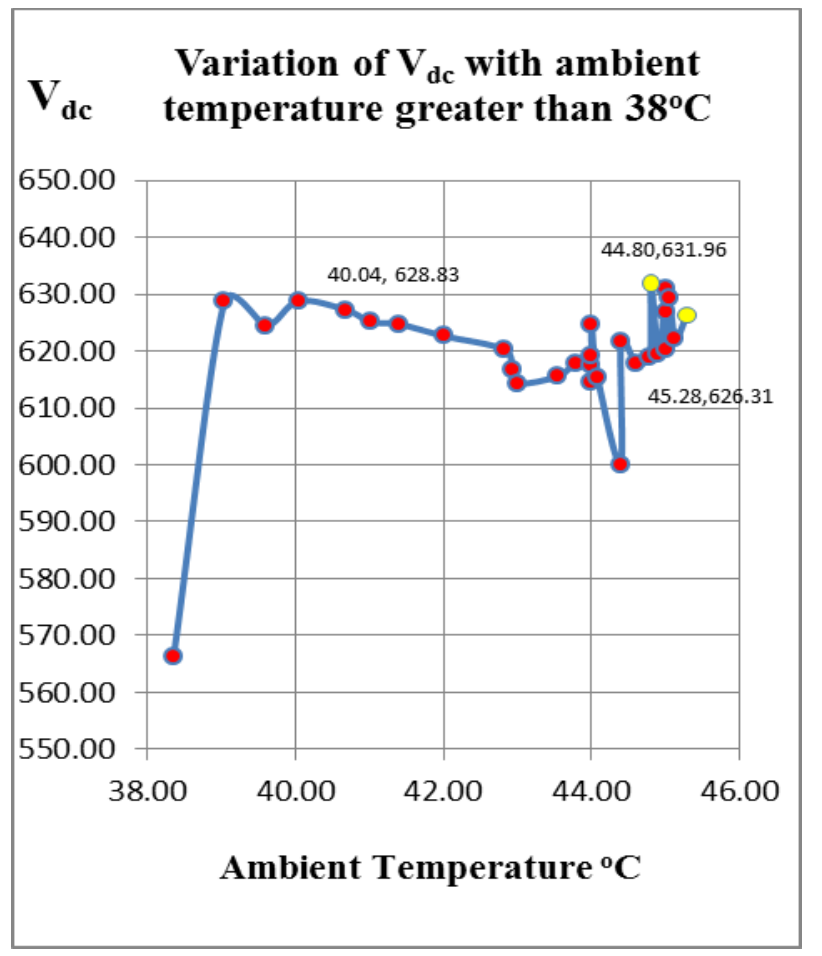

Figure 2: Variation of $\mathrm{V}_{\mathrm{dc}}$ with ambient temperature greater than $38^{\circ} \mathrm{C}$

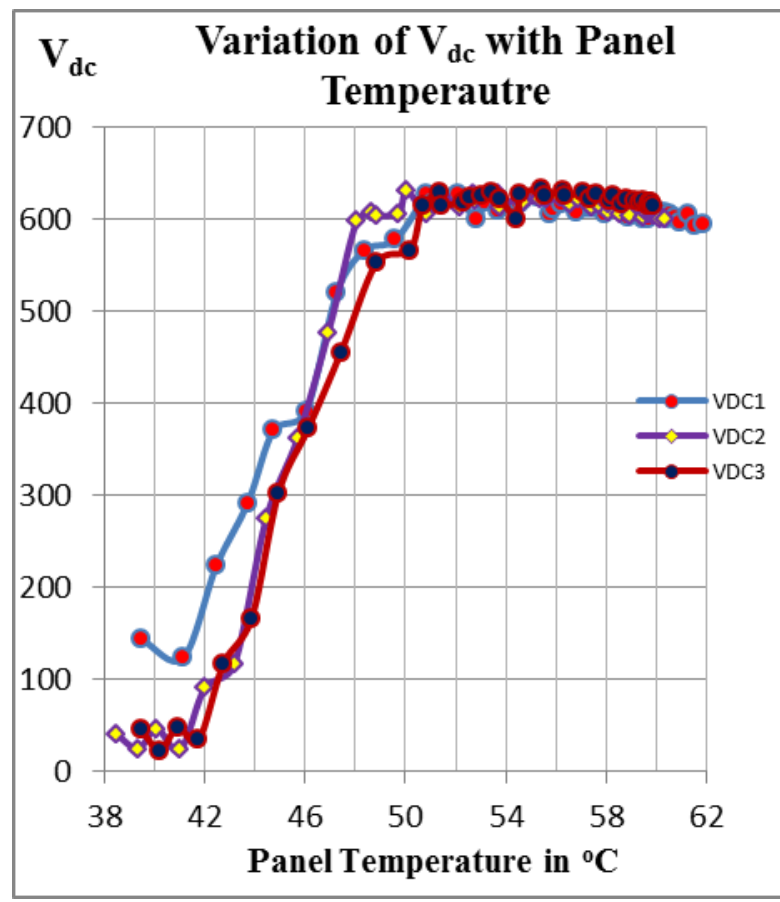

Figure 3: Variation of $V_{d c}$ with panel temperature

The above figure shows as Panel Temperature increases $V_{d c}$ also increases. Nearly stable and high $\mathrm{V}_{\mathrm{dc}}$ is obtained for panel temperature greater than $50^{\circ} \mathrm{C}$.

Figure 4 shows expanded view of variation of $\mathrm{V}_{\mathrm{dc}}$ with Panel temperature for one of the day considering Panel temperature greater than $50^{\circ} \mathrm{C} . \mathrm{V}_{\mathrm{dc}}$ decreases with increase in panel temperature greater than $52^{\circ} \mathrm{C}$ but is still much greater than $\mathrm{V}_{\mathrm{dc}}$ obtained for panel temperature less than $50^{\circ} \mathrm{C}$. High $\mathrm{V}_{\mathrm{dc}}$ that is $603.61 \mathrm{~V}$ at panel temperature $63.48^{\circ} \mathrm{C}$ is obtained. It varies between $603 \mathrm{~V}-631 \mathrm{~V}$ as panel temperature varies from $50^{\circ} \mathrm{C}$ to $64^{\circ} \mathrm{C}$.

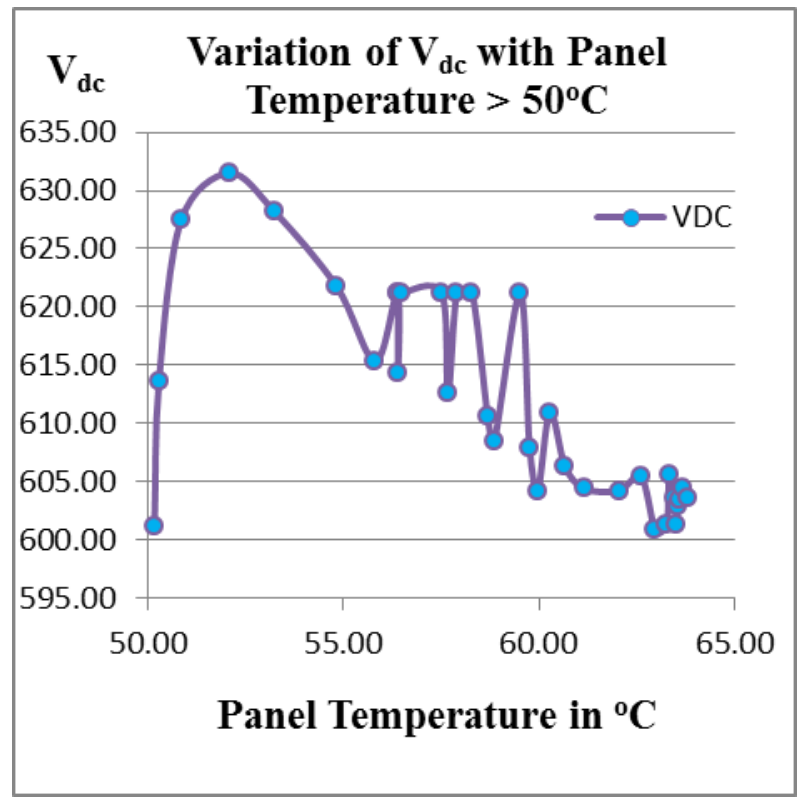

Figure 4: Variation of $\mathrm{V}_{\mathrm{dc}}$ with panel temperature $>50^{\circ} \mathrm{C}$ 


\section{RESULT AND DISCUSSION}

(i) The graph for three different days in summer particularly pre-monsoon season shows that $\mathrm{V}_{\mathrm{dc}}$ does not decrease with reference to $25^{\circ} \mathrm{C}$ ambient temperature, instead $\mathrm{V}_{\mathrm{dc}}$ increases with increase in ambient temperature. Stable and high $\mathrm{V}_{\mathrm{dc}}$ is obtained for ambient temperature greater than $39^{\circ} \mathrm{C}$ and panel temperature greater than $50^{\circ} \mathrm{C}$.

(ii) It is observed that the module works efficiently not only for ambient temperature greater than $25^{\circ} \mathrm{C}$ but far greater than $40^{\circ} \mathrm{C} . \mathrm{V}_{\mathrm{dc}}$ decreases slightly with increase in ambient temperature above $40^{\circ} \mathrm{C}$ but again increases around $44 / 45^{\circ} \mathrm{C}$.

(iii) $\mathrm{V}_{\mathrm{dc}}$ decreases with increase in panel temperature greater than about $52^{\circ} \mathrm{C}$ but is still much higher than that obtained for panel temperature less than $50^{\circ} \mathrm{C}$

(iv) No negative temperature coefficient is observed with respect to $25^{\circ} \mathrm{C}$ ambient temperature.

(v) Western Rajasthan is highly suitable for solar photovoltaic power generation.

(vi) Cooling techniques are not required at all.

(vii) Active solar tracking is required so that we can capture maximum solar irradiations in order to generate maximum power.

\section{CONCLUSIONS}

The literature and research papers all show that PV module have maximum DC voltage at $25^{\circ} \mathrm{C}$. Even the manufacturer specify negative temperature coefficient for $\mathrm{V}_{\mathrm{oc}}$ and $\mathrm{P}_{\max }$ with respect to $25^{\circ} \mathrm{C}$ ambient temperature. In contrast to existing literature, the paper brings forward a vital truth that stable and high $\mathrm{V}_{\mathrm{dc}}$ is obtained only after ambient temperature crosses $37^{\circ} \mathrm{C}$ and panel temperature is greater than $50^{\circ} \mathrm{C}$ for multicrystalline PV module. Although $\mathrm{V}_{\mathrm{dc}}$ decreases with increase in panel temperature greater than $52^{\circ} \mathrm{C}$ but the voltage obtained is still much higher than that obtained at panel temperature less than $50^{\circ} \mathrm{C}$. The reference temperature for $\mathrm{V}_{\mathrm{dc}}$ is somewhere around $52-55^{\circ} \mathrm{C}$ panel temperature and $37-42^{\circ} \mathrm{C}$ ambient temperature. Greater the DC voltage greater is the DC power, greater is the efficiency of PV module. The high temperature of Western Rajasthan can thus be utilised to generate large amount of solar power. As a further work exact reference temperature and temperature coefficient for $V_{d c}$, $\mathrm{P}_{\max }, \mathrm{V}_{\mathrm{oc}}$ needs to be evaluated correlating temperature with solar irradiation, wind velocity, humidity and other environmental parameters.

\section{NOMENCLATURE}

$\begin{array}{ll}\mathrm{V}_{\mathrm{dc}} & \text { DC Voltage } \\ \mathrm{P}_{\mathrm{dc}} & \text { DC Power } \\ \mathrm{I}_{\mathrm{dc}} & \text { DC Current } \\ \mathrm{V}_{\mathrm{mpp}} & \text { Voltage at maximum power point } \\ \mathrm{I}_{\mathrm{mpp}} & \text { Current at maximum power point } \\ \mathrm{P}_{\max } / \mathrm{P}_{\mathrm{mpp}} & \begin{array}{l}\text { Maximum Power/ Power at maximum } \\ \text { power point }\end{array} \\ \mathrm{V}_{\mathrm{oc}} & \text { Open circuit voltage } \\ \text { VDC1, } & \begin{array}{l}\text { DC voltage corresponding to three } \\ \text { VDC2, }\end{array} \\ \text { VDC3 } & \begin{array}{l}\text { different days of Pre-monsoon season } \\ \text { respely. }\end{array}\end{array}$

\section{ACKNOWLEDGMENT}

The authors would like to acknowledge the support of Shri J. K. Borgohain, Executive Director, Rajasthan Project. Oil India Lmt., Jodhpur, Shri D. C. Gogoi, Head, Technical Service, Oil India Lmt, Jodhpur; Shri Rajesh Kundoo, Incharge, PV Power Plant at Ramgarh, Jaisalmer in conducting this study.

\section{REFERENCES}

[1] Climate of Rajasthan, Volunteering India. www.volunteeringinindia.org/climate-of-rajasthan.htm

[2] Kozak, T., Maranda, W., Napieralski, A., Mey, G. D. and Vos, A. D. 2009. Influence of Ambient Temperature on the Amount of Electric Energy Produced by Solar Modules. $16^{\text {th }}$ International Conference on Mixed Design of Integrated Circuits and Systems, Poland.

[3] Polycrystalline silicon, From Wikipedia https://en.wikipedia.org/wiki/Polycrystalline_silicon

[4] Didier, T. and Richmond, B. C. 2005. Review and recommendations for improving the modelling of building integrated photovoltaic systems. Ninth International IBPSA Conference Montréal, Canada.

[5] Mayfield, R. 2010. Photovoltaic design and installation for dummies. Wiley Publishing Inc.

[6] Javaid, M. A., Hassan, M., Khan, M. S. and Shaukat, S. F. 2011. Estimation of Solar Power Efficiency in Day Time at Different Temperatures. International Journal of Electrical \& Computer Sciences, Vol. 11, No. 02, 48-52.

[7] Schwingshackla, C., Petittaa, M., Wagnera, J. E., Belluardoc, G., Moserc, D., Castellia, M., Zebischa, M. and Tetzlaff, A. 2013. Wind effect on PV module temperature: Analysis of different techniques for an accurate estimation, Energy Procedia, Vol. 40, 77-86.

[8] Based on data from the National Renewable Energy Laboratory (NREL) published Solar Radiation Data Manual for Flat-Plate and Concentrating Collectors for a South facing, approximately $15^{\circ}$ tilted system, located in Los Angeles, CA.

[9] Chaturvedi, D. K. and Sharma, S. 2015. An experimental study and verification of the facts related to factors affecting the performance of solar PV systems. Fifth International Conference on Communication Systems and Network Technologies.

[10] Young, C., Thelen, J. and Nehrir, H. 2014. Design and Implementation of a Low-cost Solar Photovoltaic Experimental Station for Education Enhancement. $46^{\text {th }}$ IEEE North American Power Symposium.

[11] Gaur, A. and Tiwari, G. N. 2013. Performance of Photovoltaic Modules of Different Solar Cells. Journal of Solar Energy. Hindawi Publishing Corporation.

[12] Touati, F., Massoud, A., Hamad, J. A. and Saeed, S. A. 2013. Effects of Environmental and Climatic Conditions on PV Efficiency in Qatar. International Conference on Renewable Energies and Power Quality, Bilbao (Spain), $20^{\text {th }}$ to $22^{\text {th }}$ March, Renewable Energy and Power Quality Journal, Vol. 11.

[13] Green, M. A. 2006. Third Generation Photovoltaics. Advanced Solar Energy Conversion, Springer. 
[14] Mitavachan, H., Gokhale, A. and Srinivasan, J. 2011. A case study of 3-MW scale grid-connected solar photovoltaic power plant at Kolar, Karnataka, Performance assessment \& recommendations, REPORT IISC-DCCC.

[15] Yaacob, M. E., Hizam, H., Khatib, T., Radzi, M. A. M., Gomes, C., Adam, M. B., Marhaban, M. H. and Elmenreich, W. 2014. Modelling of photovoltaic array temperature in a tropical site using generalized extreme value distribution, Journal of Renewable and sustainable Energy, Vol. 6, No 3.

[16] Dinçer, F. and Meral, M. E. 2010. Critical Factors that Affecting Efficiency of Solar Cells. Smart Grid and Renewable Energy. Vol. 1, 47-50.

[17] Dubey, S., Sarvaiya, J. N. and Seshadri, B. 2013. Temperature Dependent Photovoltaic (PV) Efficiency and Its Effect on PV Production in the World A Review. PV Asia Pacific Conference 2012, Energy Procedia, Vol. $33,311-321$
[18] Katkar A. A., Shinde, N. N. and Patil, P. S. 2011. Performance \& Evaluation of Industrial Solar Cell w.r.t. Temperature and Humidity. IJRMET, Vol. 1, No. 1.

[19] Skoplaki, E. and Palyvos, J. A. 2009. On the temperature dependence of photovoltaic module electrical performance: A review of efficiency/power correlations. Solar Energy, Vol. 83, 614-624.

[20] Pradhan, A., Ali, S. M. and Jena, C. 2013. Analysis of Solar PV cell Performance with Changing Irradiance and Temperature. International Journal of Engineering and Computer Science, Vol. 2, No. 1, 214-220.

[21] California Energy Commission. A Guide to Photovoltaic (PV) System Design and Installation. report, page 8, section 2.3.1 Factors Affecting Output, Standard Test Conditions. www.energy.ca.gov/reports/2001-09-04_500 -01- 020.PDF 